\title{
DESIGN, CONSTRUCTION AND EVALUATION OF RUNOFF WATER HARVESTING POND FOR SMALLHOLDER FARMING
}

\author{
Bayan Ahmed $1 \bowtie$, Fikadu Gemeda $2 \square$ \\ ${ }^{1}$ Oromia Agricultural Research Institute, Asella Agricultural Engineering Research Center \\ Asella, Ethiopia.
}

Received 24 August2021

Accepted 8 September 2021

Published 30 September2021

\section{CorrespondingAuthor}

Bayan Ahmed, bayahm@gmail.com

DOI

10.29121/granthaalayah.v9.i9.2021. 4223

Funding: This research received no specific grant from any funding agency in the public, commercial, or not-for-profit sectors.

Copyright: (C) 2021 The Author(s). This is an open access article distributed under the terms of the Creative Commons Attribution License, which permits unrestricted use, distribution, and reproduction in any medium, provided the original author and source are credited.

\section{ABSTRACT}

For the reason of Rainfall shortage and variability constrain, crop production in Ethiopia is the main problem. For this supplementary irrigation by run off harvesting is strategic pathway to enhancing agricultural productivity and increasing smallholder farmers' income. Therefore, this study was conducted to Design, construct and evaluate runoff water harvested pond for supplementary irrigation on onion crop to addressing inherent crop failures under the rain fed agriculture due to mainly erratic rainfall. For this design, climatic and soil data were input to determine seasonal crop water requirement (CWR). The evaporation loss of water from water surface of pond was calculated. Then the performances of water harvested verses area irrigate were evaluated. Seasonal volume crop water requirement (CWR) of onion for farm area $2500 \mathrm{~m} 2$, evaporation loss of water from pond water surface of $121 \mathrm{~m} 2$ and total volume of seasonal water need were $382.05,53.38$ and $435.43 \mathrm{~m} 3$ respectively. The geo-membrane laminated water harvester that has capacity of $223 \mathrm{~m} 3$ was designed and constructed. From on field performance shows, this volume of water harvested twice a year can irrigate 0.25 ha by supplementary irrigation using water saving irrigation technology by treadle pump was produced 4.2 tone/ha. The investment, operation and production costs were $63,116,1,125$ and 6,675 ETH birr respectively. The total cost was 70,916 birr and growth return of 0.25 ha was $15,750 \mathrm{birr} /$ year $(1050 \mathrm{~kg} * 15 \mathrm{birr} / \mathrm{kg}$ ). This shows the farmer can return $22.21 \%$ of their investment cost. So, it is recommended to the government and non-government to initiate the farmers at lower stream of the catchment to harvest run off water and use for supplementary irrigation to increase their income.

Keywords: Construction, Harvesting, Smallholder, Rainfall

\section{INTRODUCTION}

Agriculture is the backbone of Ethiopian economy. It accounts for a little over 50 percent of the GDP, 90 percent of the total export revenue and employs 85 percent of the country's labor force and the main income generating sector for the majority of the rural population. It provides row materials for more than $70 \%$ of the country's industries CSA (Central Statistical Agency) (2013). The dependency of farming system on rain fed agriculture has made the Ethiopia's agricultural economy extremely exposed to weather and climate effects Conway and Schipper (2011). The failure of rain and the occurrence of drought or consecutive dry spells during the growing season zled to crop failure. This in turn results in food shortage and contributes to food insecurity and reduced income generation from agricultural products sale Teshome et al. (2010).

Rain-fed agriculture in Ethiopia is suffering from moisture stress which is a 
major limiting factor for successful crop production. Many of Ethiopian smallholders depending on rain-fed agriculture are food insecure. In many places, the amount of rainfall and the duration of rainy season are highly variable frequently resulting in low crop yields and associated low incomes. Because of large differences in rainfall distribution between years and within years coupled with short rainy seasons, rainfed agriculture is very susceptible to water shortage. As the scarcity of water is rapidly increasing everyday particularly during the summer season, the demand for water also substantially increases Teweldebrihan (2014).

Water harvesting can best be described as all activities to collect available water resources, temporarily storing excess water for use when required, especially in periods of drought or when no perennial resources are available. The starting point is the collection of natural water resources from rainwater, fog, runoff water, groundwater or even waste water, which otherwise would have escaped. World water resources are facing dramatic changes as a result of global climate change, high water demands, population growth, industrialization and urbanization.

To respond to water scarcity and unequal distribution, small-scale water harvesting techniques provide a direct solution, especially in rural and droughtprone areas. Local storage of water is increasingly important for ensuring water availability and food security for rural and urban populations, especially in developing countries. This is particularly the case in areas with dry seasons where perennial rivers and fresh groundwater are not available or difficult to reach (NWP 2007).

The research conducted at semi-arid in Kenya (Machakos district) and Burkina Faso (Ouagouya) during 1998-2000 indicates a significant scope to improve water productivity in rainfed agriculture through supplemental irrigation, especially if combined with soil fertility management. The results were more promising on soils with higher water holding capacity on which crops seem to cope better with intraseasonal dry spells Fox and Rockstrom (2000)

In Ethiopia, promotion and application of rainwater harvesting techniques as alternative interventions to address water scarcity were started through government-initiated soil and water conservation programmers.

Today, smallholder farmers feel increasing vulnerability to water shortages; consequently, the demand for water storage is rising. The more unreliable the natural supply becomes, the greater the need for water storage. With stored water accessible, farmers feel less vulnerable to climatic fluctuations, and thus are encouraged to invest more in agricultural inputs and equipment to improve their farming productivity Getachew (1999).

One of the main pillars of the Ethiopian government food security strategy is the development and implementation of water harvesting schemes mainly in the drought prone and chronically drought affected areas of the country. But most of farmers have not trained to harvest water and some of water harvester constructed was not depend on catchment run off and silt protector is not properly designed for this reason most of water harvested is filled by sediment.

Therefore, to minimize the negative impacts of runoff water generated from catchment area (erosion, flooding) and optimizing its benefits as supplementary source for addressing inherent crop failures under the rain fed agriculture due to mainly erratic rainfall this study was conducted with the objective of evaluating runoff water harvesting by supplementary irrigation on onion crops at Keta Barend Kebele. 


\section{MATERIAL AND METHODS}

\subsection{STUDY AREA}

The study was conducted at West Arsi zone, Dodola district of Keta Barend kebele. The crop used for this study was red onion and treadle pump was used to transport water from harvester to irrigating field by over showering. The field area used for evaluation was $2500 \mathrm{~m} 2$.

\subsection{DATA COLLECTION}

The primary and secondary were collected. The data collected were farmers' estimations on direction of water flow, meteorological data; laboratory work was done to assess the soil physical and chemical property.

\subsubsection{SOIL DATA}

To determine the soil texture disturbed soil samples by auger and bulk density, moisture content at field capacity (FC) and permanent wilting point (PWP) undisturbed soil samples were collected by core sampler from two depths $0-30 \mathrm{~cm}$ and $30-60 \mathrm{~cm}$ at three points diagonally of the experimental site and were taken to laboratory for analysis.

\subsubsection{CLIMATIC DATA}

The minimum and maximum temperature, relative humidity, wind speed and daily sunshine hour of 20 years were collected from National Meteorological Agency to determine mean daily reference evapotranspiration (ETo) of the study area.

\subsubsection{IRRIGATION WATER REQUIREMENT}

CROPWAT version-8 was used and soil data and twenty years climatic data were fed to calculate the reference evapotranspiration (ETo) of the study area.

$$
\begin{aligned}
& \text { ETc }=\text { ETo } \times \text { Kc } \\
& \text { Where: } \\
& \text { ETc }=\text { crop evapotranspiration }(\mathrm{mm} / \text { day }) \\
& \text { ETo }=\text { reference crop evapotranspiration }(\mathrm{mm} / \text { day }) \\
& \text { Kc }=\text { crop coefficient }
\end{aligned}
$$

\subsubsection{SOIL INFILTRATION CAPACITY}

Infiltration rate was measured using double ring infiltrometer. The measurement was done at 15,30,45,60-minute intervals at randomly selected study site.

\subsubsection{RUN OFF COLLECTION}

Due to site selected at the tail of large catchment the volume of run off collected was fixed by field to irrigate depending on crop water requirement need. To collect run off the rectangular canal and silt trap was constructed and diverted from flooding tail point of catchment. 


\subsubsection{SEDIMENT LOAD ANALYSIS}

For sediment load determine, two methods were used and used for design water harvester volume of sediment (dead storage) determine. The first was during water harvest and second was after water harvested. For the first option one liter of runoff sample was taken from the inlet and outlet of the silt trap.

\subsubsection{WATER LOSS/EVAPORATION}

This lost water is referred to as consumed, because it is removed from the system. In some cases, this water consumption can be quite substantial. This will be calculated as stated by FAO (2015).

$$
\mathrm{E}=\mathrm{Kw}^{*} \mathrm{ETo}
$$

where $\mathrm{E}$ is water loss/evaporated, $\mathrm{Kw}$ is the coefficient for open water, ETo is reference ET for short Grass. FAO (1998) suggests a Kw value of 0.65 at initial and 1.25 at development of the crop.

\subsection{DETERMINATION OF THE STORAGE CAPACITY OF RWH POND}

For determining volume of water harvester, sessional crop water and evaporation from surface water harvester and volume of sediment occupied was identified. Then truncated square pyramid formula was used.

$$
\begin{aligned}
& \text { Volume: } V=(a 2+a b+b 2) h \\
& \text { Lateral Area: } F=2(a+b) \\
& \text { Surface Area: } S=F+a 2+b 2
\end{aligned}
$$

Where: $b=$ the bottom surface of the pond

$a=$ top surface of the pond and

$\mathrm{h}=$ the depth of the pond

\subsection{LAMINATING AND FENCING}

To prevent seepage loss, surface area of water harvesting pond was calculated using equation (6) and fitting geo-membrane plastic of $0.5 \mathrm{~mm}$ was laminated. The fence was constructed to prevent the interference of animals and children.

\subsection{PERFORMANCE OF WATER HARVESTED}

The performance of water harvested was evaluated by theoretical irrigating capacity and on farm irrigating capacity of harvester depending on climatic and soil of the area, volume of sediment occupied, silt trap efficiency and water productivity

\subsubsection{VOLUME SEDIMENT OCCUPIED}

The silt passed the silt trap and entered harvesters were determined by area method after water used. 


\subsubsection{SILT TRAP EFFICIENCY (STE)}

The silt trap efficiency of the reservoir is the ratio of sediment caught in the storage and total load entering with the runoff.

\subsubsection{WATER PRODUCTIVITY (WP)}

Is the ratio of the physical yield of a crop ( $\mathrm{kg}$ ) and the amount of water consumed (m3), including both rainfall and supplemental irrigation

$$
\mathrm{WP}=\frac{\text { Yeild }}{\text { Amount of water consumed }}
$$

\subsubsection{ECONOMIC ANALYSIS}

Economic analysis was computed based on investment, operation and production cost of the experiment. The investment and operation cost was by adding material need for the contraction and cost of man power consumed during excavation and on field operation and production. The total gross return was obtained by multiplying yield with unit price of the product.

\subsection{STATISTICAL ANALYSIS}

The results were analyzed by descriptive statistically using Microsoft excel and compared averages result of parameters.

\section{RESULT AND DISCUSSION}

\subsection{SOIL PHYSICAL AND CHEMICAL PROPERTIES}

The laboratory result of soil physical and chemical properties at study site was presented in Table 1. From this table, the soil texture was clay and average soil bulk density was $1.13 \mathrm{~g} / \mathrm{cm} 3$. Field capacities (FC) and permanent wilting point (PWP) were 38.2 and 23.7 (\%) respectively and total available water (TAW) was 145 $\mathrm{mm} / \mathrm{m}$.

\begin{tabular}{|cc|}
\hline Table 1 Soil physical and chemical property & \\
\hline Soil property & Results \\
\hline Soil Particle size distribution & Sand $(\%)=19$ Silt $(\%)=29$ Clay $(\%)=52$ \\
Texture & Clay \\
pH & 5.8 \\
EC & 0.18 \\
OC & 2.26 \\
OM & 3.9 \\
\hline Bulk density $\left(\mathrm{g} / \mathrm{cm}^{3}\right)$ & 1.32 \\
\hline FC $(\% \mathrm{Vol})$ & 38.2 \\
\hline PWP $(\% \mathrm{Vol}$ & 23.7 \\
\hline TAW $(\mathrm{mm} / \mathrm{m})$ & 145 \\
\hline
\end{tabular}


$\mathrm{OM}=$ Organic matter, $\mathrm{FC}=$ Field Capacity, $\mathrm{PWP}=$ Permanent wilting point, $\mathrm{TAW}=$ Total available water

\subsection{REFERENCE EVAPOTRANSPIRATION AND CROP WATER REQUIREMENTS}

Table 2 shows daily and monthly reference evapotranspiration (ETo), effective rain falls and irrigation water requirements of onion crop at study area. This was used to determine volume of water harvested relation to area to irrigate. The minimum reference evapotranspiration was occurred $1.87 \mathrm{~mm} /$ day in December, maximum $4 \mathrm{~mm} /$ day in February and mean of $3.23 \mathrm{~mm} /$ day. The sessional reference evapotranspiration (ETo), effective rain falls and irrigation water requirements were $361.5,107$ and $254.6 \mathrm{~mm}$ respectively.

\begin{tabular}{|c|c|c|c|c|c|c|c|}
\hline Month & Decade & Stage & $\begin{array}{c}\text { Kc } \\
\text { coeff }\end{array}$ & $\begin{array}{c}\text { ETc } \\
\text { mm/day }\end{array}$ & $\begin{array}{c}\text { ETc } \\
\mathrm{mm} / \mathrm{dec}\end{array}$ & $\begin{array}{l}\text { Eff rain } \\
\mathrm{mm} / \mathrm{dec}\end{array}$ & $\begin{array}{l}\text { Irr. Req. } \\
\text { mm/dec }\end{array}$ \\
\hline Nov & 3 & Init & 0.5 & 1.88 & 18.8 & 3.7 & 5.7 \\
\hline Dec & 1 & Init & 0.5 & 1.87 & 18.7 & 6.1 & 12.6 \\
\hline Dec & 2 & Deve & 0.61 & 2.28 & 22.8 & 4.7 & 18.1 \\
\hline Dec & 3 & Deve & 0.82 & 3.07 & 33.8 & 6.8 & 27 \\
\hline Jan & 1 & Mid & 0.99 & 3.71 & 37.1 & 9.8 & 27.4 \\
\hline Jan & 2 & Mid & 1 & 3.77 & 37.7 & 11.7 & 26 \\
\hline Jan & 3 & Mid & 1 & 3.85 & 42.3 & 11.5 & 30.9 \\
\hline Feb & 1 & Mid & 1 & 3.93 & 39.3 & 10.7 & 28.6 \\
\hline Feb & 2 & Late & 1 & 4 & 40 & 10.6 & 29.4 \\
\hline Feb & 3 & Late & 0.94 & 3.78 & 30.2 & 11.9 & 18.4 \\
\hline Mar & 1 & Late & 0.85 & 3.44 & 34.4 & 12.8 & 21.6 \\
\hline Mar & 2 & Late & 0.77 & 3.16 & 15.8 & 6.8 & 9 \\
\hline Total & & & & & 361.5 & 107 & 254.6 \\
\hline
\end{tabular}

$\mathrm{Kc}=$ Crop coefficient, ETc $=$ Evapotranspiration of the crop

\subsection{WATER LOSS/EVAPORATION CALCULATION}

The loss of water from upper surface area of water body was estimated using the equation 2 throughout session. Then the volume of water lost was considered as consumed on design. From the table 3 blow the volume of water lost due to evaporation from the surface of the body during crop growing season was $53.38 \mathrm{~m} 3$ was calculated.

\begin{tabular}{|ccccccc|}
\hline Table 3 Water loss from water body of crop growing & & & \\
\hline Month & $\begin{array}{c}\text { Average ETc } \\
\text { (mm/dec) }\end{array}$ & Kw & $\begin{array}{c}\text { Loss } \\
\mathbf{( m m )}\end{array}$ & $\begin{array}{c}\text { Loss } \\
\mathbf{( m )}\end{array}$ & $\begin{array}{c}\text { Area } \\
\left(\mathbf{m} \mathbf{m}^{\mathbf{2}}\right.\end{array}$ & $\begin{array}{c}\text { Volume of water } \\
\mathbf{( m}^{\mathbf{3}} \mathbf{)}\end{array}$ \\
\hline Nov & 18.8 & 0.65 & 12.22 & 0.01 & 121 & 1.48 \\
\hline Dec & 18.7 & 0.65 & 12.155 & 0.01 & 121 & 1.47 \\
\hline Dec & 22.8 & 1.25 & 28.5 & 0.03 & 121 & 3.45 \\
\hline Dec & 33.8 & 1.25 & 42.25 & 0.04 & 121 & 5.11 \\
\hline
\end{tabular}


Design, construction and evaluation of runoff water harvesting Pond for smallholder farming

\begin{tabular}{ccccccc}
\hline Jan & 37.1 & 1.25 & 46.375 & 0.05 & 121 & 5.61 \\
\hline Jan & 37.7 & 1.25 & 47.125 & 0.05 & 121 & 5.70 \\
\hline Jan & 42.3 & 1.25 & 52.875 & 0.05 & 121 & 6.40 \\
\hline Feb & 39.3 & 1.25 & 49.125 & 0.05 & 121 & 5.94 \\
\hline Feb & 40 & 1.25 & 50 & 0.05 & 121 & 6.05 \\
\hline Feb & 30.2 & 1.25 & 37.75 & 0.04 & 121 & 4.57 \\
\hline Mar & 34.4 & 1.25 & 43 & 0.04 & 121 & 5.20 \\
\hline Mar & 15.8 & 1.25 & 19.75 & 0.02 & 121 & 2.39 \\
\hline
\end{tabular}

\subsection{DESIGN OF WATER HARVESTER}

For determining volume of water harvester, sessional crop water and evaporation from surface water harvester and volume of sediment occupied. For determining volume of water harvester, sessional crop water and evaporation from water surface were 382.05 and $53.38 \mathrm{~m}^{3}$ respectively. The total volume of water used for design of harvester was $435.43 \mathrm{~m}^{3}$

\begin{tabular}{|c|c|c|c|c|c|}
\hline Month & $\begin{array}{l}\text { CWR } \\
(\mathrm{mm})\end{array}$ & $\begin{array}{l}\text { Irrigated area } \\
\quad \text { in }\left(\mathrm{m}^{2}\right)\end{array}$ & $\begin{array}{c}\text { Volume of water } \\
\text { need in }\left(\mathrm{m}^{3}\right)\end{array}$ & $\begin{array}{c}\text { Volume of } \\
\text { water loss in } \\
\left(\mathrm{m}^{3}\right)\end{array}$ & $\begin{array}{c}\text { Total volume of } \\
\text { water in }\left(\mathrm{m}^{3}\right)\end{array}$ \\
\hline Nov & 5.7 & 1500 & 8.55 & 1.48 & 10.03 \\
\hline Dec & 12.6 & 1500 & 18.9 & 1.47 & 20.37 \\
\hline Dec & 18.1 & 1500 & 27.15 & 3.45 & 30.6 \\
\hline Dec & 27 & 1500 & 40.5 & 5.11 & 45.61 \\
\hline Jan & 27.4 & 1500 & 41.1 & 5.61 & 46.71 \\
\hline Jan & 26 & 1500 & 39 & 5.70 & 44.7 \\
\hline Jan & 30.9 & 1500 & 46.35 & 6.40 & 52.75 \\
\hline Feb & 28.6 & 1500 & 42.9 & 5.94 & 48.84 \\
\hline Feb & 29.4 & 1500 & 44.1 & 6.05 & 50.15 \\
\hline Feb & 18.4 & 1500 & 27.6 & 4.57 & 32.17 \\
\hline Mar & 21.6 & 1500 & 32.4 & 5.20 & 37.6 \\
\hline Mar & 9 & 1500 & 13.5 & 2.39 & 15.89 \\
\hline \multicolumn{3}{|c|}{ Total } & 382.05 & 53.38 & 435.43 \\
\hline
\end{tabular}

But $223 \mathrm{~m}^{3}$ the harvester that have the bottom surface of $6 \mathrm{~m}$ top surface of 11 $\mathrm{m}$ and depth of $3 \mathrm{~m}$ the pond was designed and to make this study more economical the water harvester capacity decreed by two-fold and water harvesting made at two times. Its lateral surface area was laminated by $238 \mathrm{~m} 2$ geo-membrane. 


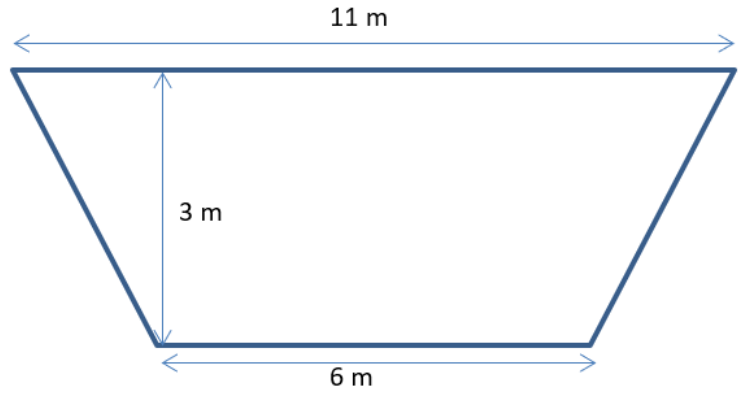

Fig 1 Size of designed water harvester

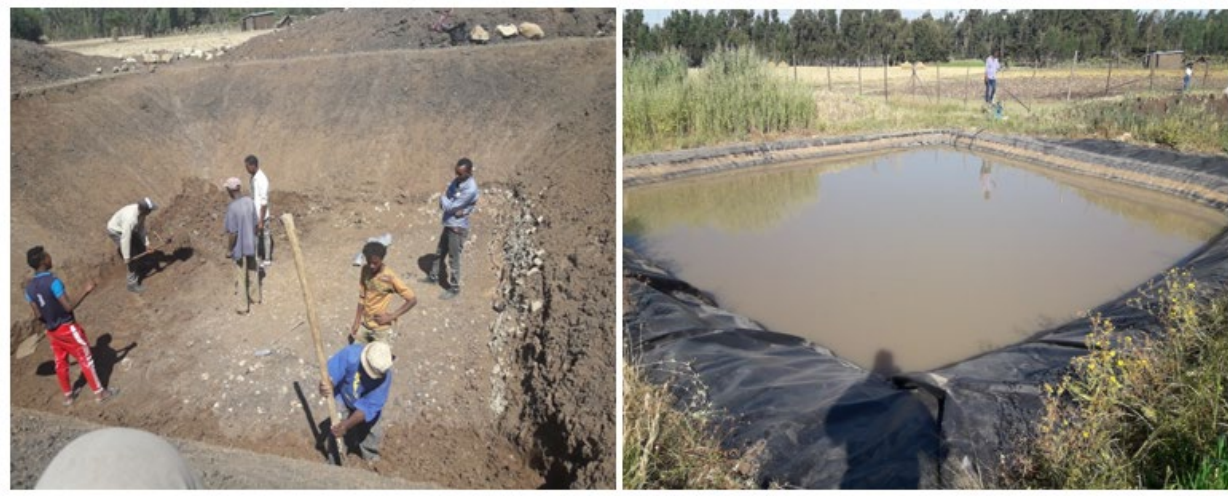

Fig 2 Water harvester pond constructed

\subsection{WATER PRODUCTIVITY (WP)}

The was calculated using yield of $4200 \mathrm{~kg} / \mathrm{ha}$ and sessional water requirement of $4500 \mathrm{~m}^{3} /$ ha was $0.93 \mathrm{~kg} / \mathrm{m}^{3}$

\subsection{ESTIMATION OF COSTS FOR A RUN OFF HARVESTER WITH 223 M3 CAPACITY}

The following Economic analysis was computed based on investment, operation and production cost of the experiment. The total investment, operation and production cost was 63,116 ETH birr.

\begin{tabular}{|cccc}
\hline Table $\mathbf{5}$ The investment cost of water harvesting pond & \\
\hline Materials & Quantity & Unit cost in birr & Total cost in birr \\
\hline Excavation & $223 \mathrm{~m}^{3}$ & 150 & 33,450 \\
\hline Geo-membrane plastic $\mathbf{0 . 5 m m}$ & $238 \mathrm{~m}^{2}$ & 65 & 15,470 \\
\hline Geo-membrane binding & $238 \mathrm{~m}^{2}$ & 42 & 9,996 \\
\hline Fence wire & $36 \mathrm{~kg}^{2}$ & 60 & 2160 \\
\hline Nail 3, 5,7,9 & $3 \mathrm{~kg}$ & 30 & 90 \\
\hline Kanch & $55 \mathrm{pcs}$ & 20 & 1100 \\
\hline korkora & $1 \mathrm{pcs}$ & 100 & 700 \\
\hline Daily lobar fence constriction & 10 & 75 & 750 \\
\hline
\end{tabular}




\begin{tabular}{|cccc|}
\hline $\begin{array}{c}\text { Total cost } \\
\text { Operation/session }\end{array}$ & & 63,116 \\
\hline Water lifting by Treadle pump & 15 & 75 & 1125 \\
\hline Total & & & 1125 \\
\hline Production for $\mathbf{0 . 2 5}$ ha & & & \\
\hline Land preparation & 2 time & 500 & 1000 \\
\hline Seed & Bed & 800 & 800 \\
\hline Fertilizer & 1.5 kunt & 1500 & 2250 \\
\hline Cultivation & 10 & 75 & 750 \\
\hline Chemicals & & & 1500 \\
\hline Harvesting & 5 & 75 & 375 \\
\hline Total & & & 6,675 \\
\hline Over all total cost & & 70,916 \\
\hline
\end{tabular}

\subsubsection{NET RETURN COST}

This capacity of harvester was irrigating $0.25 \mathrm{ha} /$ year and its total cost was 70,916 birrs. The growth return of 0.25 ha was 15,750 birr $\left(1050 \mathrm{~kg}^{*} 15 \mathrm{birr} / \mathrm{kg}\right)$. This shows the farmer can return $22.21 \%$ of their investment cost.

\section{SUMMARY, CONCLUSION AND RECOMMENDATIONS 4.1. SUMMARY AND CONCLUSION}

Supplementary irrigation by run off harvesting is strategic pathway to reduce poverty in rural drought prone areas for enhancing agricultural productivity and boosting farm income.

For the study to Design, construction and evaluation of runoff water harvesting Pond for supplementary irrigation the climatic and soil data were input to determine seasonal crop water requirement of onion and evaporation loss of water from water surface.

From the result obtained the Seasonal volume of crop water requirement of onion for farm area $2500 \mathrm{~m} 2$ and evaporation loss of water from water surface of $121 \mathrm{~m} 2$ and total volume of seasonal water need to irrigate this area were $382.05,53.38$ and $435.43 \mathrm{~m} 3$ respectively and used for the design. The geomembrane laminated water harvester that has capacity of $223 \mathrm{~m} 3$ (6 m bottom width and $11 \mathrm{~m}$ top width) was designed and constructed.

Then the performances of water harvested verses area irrigate were evaluated. From on field performance shows, this volume of water harvested twice can irrigate 0.25 ha by supplementary irrigation using water saving irrigation technology (treadle pump) by over showering and was produced 4.2 tone/ha.

\subsection{RECOMMENDATION}

The extension team has work to initiate the farmers at lower stream of the catchment to harvest run off water and use for supplementary irrigation to increase their income. 


\section{REFERENCES}

CSA (Central Statistical Agency). (2013). Revised Report on the 2012 / 2013 Private peasant holdings, meher season, area and production of major crops Survey. Statistical Bulletin 532. Addis Ababa: The Federal De

Conway, D. and E.L.F. Schipper (2011), Adaptation to climate change in Africa: Challenges and opportunities identified from Ethiopia. Global Environmental Change, 21(1): p. 227-237. Retrieved from https://doi.org/10.1016/j.gloenvcha.2010.07.013

FAO (Food and Agriculture Organization). (2015). Evaporation from artificial lakes and reservoirs.

Fox, P., Rockstrom, J., (2000). Water harvesting for supplemental irrigation of cereal crops to overcome intra-seasonal dry spells in the Sahel. Phys. Chem. Earth (B) 25 (3), 289-296. Retrieved from https://doi.org/10.1016/S14641909(00)00017-4

Getachew Alem, (1999). Rain water harvesting in Ethiopia: an overview

Netherlands Water Partnership (NWP, 2007). Smart Water Harvesting Solutions. Examples of innovative, low-cost technologies for rain, fog, runoff water and groundwater. in Stockholm, Sweden.

Teshome, A., E. Adgo, and B. Mati, (2010), Impact of water harvesting ponds on household incomes and rural livelihoods in Minjar Shenkora district of Ethiopia. Ecohydrology \& Hydrobiology, 10(2): p. 315- 322. Retrieved from https://doi.org/10.2478/v10104-011-0016-5

Teweldebrihan, M. D. (2014). Optimizing Intensified Runoff from Roads for Supplemental Irrigation: Tigray Region, Ethiopia, (April). Retrieved from http://www.rainfoundation.org/wpcontent/uploads/2017/10/Optimising-runoff-from-roads-forirrigation.pdf 